\title{
Conquering a Male Domain: The Female Spectator and The Pershyi Vinok
}

\author{
Lyudmyla Lutsenko ${ }^{1, *}$ Iryna Dyrda ${ }^{1}$ Anna Tomilina ${ }^{1}$ Maryna Maloivan ${ }^{1}$ \\ Iryna Zorenko ${ }^{1}$
}

\author{
${ }^{1}$ Kryvyi Rih State Pedagogical University, Ukraine \\ *Corresponding author.Email: lyudmylalutsenko@gmail.com
}

\begin{abstract}
This research paper aims at giving a broad outline of pioneering journalistic projects in England and Ukraine periodicals The Female Spectator and The Pershyi Vinok which were written by and for women. It surveys a scope of the two collections, the main genre forms, themes, characters as well as their significance in the history of English and Ukrainian literary journalism and literature in general. The authors hope that the article will find a wide audience interested in prominent and less known names of those women writers who not only opened up a new era of conquering the domain originally taken by men but contributed to the rise of literary journalism in both countries as well. By using recurring themes, motifs, myths the editors of the women's journals Haywood, Kobrynska, Pchilka together with other women authors created heroines enabling the reader to see the patters of feminine behaviour and ponder over the problem of quest for female identity. The study clearly indicates that these fascinating journalistic projects hold a significant place in proto-feminist and feminist history of both countries considering the fact that they made women's concerns sound palatable and important, assisted English and Ukrainian women to define their roles within the then social context and challenged the status quo of the deeply ingrained norms related to a woman's place in society.
\end{abstract}

Keywords: Literary Journalism, Eliza Haywood, Nataliia Kobrynska, Olena Pchilka, The Female Spectator, The Pershyi Vinok.

\section{INTRODUCTION}

In this research paper we focus our attention on pioneers in women literary journalism in England and Ukraine. Their names are Eliza Haywood (1693?1756), Nataliia Kobrynska (born Ozarkevych) (18511920) and Olha Drahomanova-Kosach (1849-1930), known by her literary name of Olena Pchilka.

At first sight, selecting as a research area an English author Eliza Haywood and two Ukrainian writers might seem arbitrary in a number of angles. In the first place, these women lived in different countries and historical epochs as well as came from families with different social background. For instance, Haywood was a product of London where her father was a shopkeeper, though some scholars claim that she was born in Shropshire, a West Midlands county. In her 1724 dedication to The Fatal Secret she mentions that as a woman, she was "deprived of those advantages of education which the other sex enjoy" [ 6 , p. 207]. Kobrynska's place of birth is Beleluia in the Galyciia Province of the Habsburg Monarchy where her parents (the Reverend Iwan Ozarkevych and Teofiliia Okunevska) lived. Pchilka was born into a privileged family of landowners in a small provincial town of Hadiach close to Poltava in Eastern Ukraine, attended an exclusive girls' school in Kyiv, where she studied world literature and foreign languages.

Eliza Haywood did not find happiness with a moderately successful clergyman, Valentine Haywood, and escaped from his house to appear at the Smock Alley Theatre in Dublin. Some accounts suggest that she had been deserted by her husband to raise their children alone. After a short affair with a poet Richard Savage (1697-1743) she had a twenty year open relationship with her colleague and collaborator William Hatchett (1701-1760s?). 
Nataliia Kobrynska had no children, enjoyed only a 10 year long married life with a priest, and after her husband's death never remarried. Olena married a lawyer Petro Kosach at the age of nineteen, and became a devoted mother for two sons and four daughters.

Nataliia Kobrynska's and Olena Pchilka's reputations were spotless, whereas Eliza Haywood was a woman of ill repute as scandal had been always attached to her name. She had to suffer from vicious attacks of Alexander Pope, unflattering characterizations by Fielding and other leading figures. Overall, Haywood's status within academia is far from being defined yet and has always been varied from contempt and oblivion to finding a deservedly prominent place in the canon of eighteenth-century.

However, Eliza Haywood, Nataliia Kobrynska and Olena Pchilka share several common features: they all played an important role in the then literary London, Lviv and Kyiv scenes and were mistresses of multiplicity who wrote original poetry, plays, short fiction, they were also successful translators. In particular, Eliza Haywood is traditionally referred to as "perhaps the most voluminous female writer this kingdom ever produced" [1, p. 316]. The author's various literary metamorphosis is reflected in multiple genres - prose fiction, drama, poetry, translation, and other fictions, has only one exception, which is autobiography. It should be noted that the number of her writings is impressive. George Whicher listed 67 literary works authored by Haywood; Dale Spender extended the list to 94; in Patrick Spedding's opinion [22], Haywood's canon includes 72 works. Among the newly discovered books are: The City Widow (1728), Arden of Feversham (1736), Sopha: a Moral Tale (1742), Memoirs of an Unfortunate Young Man (1742), Memoirs of a Man of Honour (1747), Dalinda: Or, the Double Marriage (1749), as well as The History of Leonora Meadowson, published posthumously in 1788 .

Nataliia Kobrynska's literary heritage is presented by prose (Vyborets (The Voter), Dukh chasu (Spirit of the Times), Zhydivska dytyna (A Jewish Child) and others), scientific essays, psychological sketches and a collection of short stories with its major theme - the war (Kin (A Horse), Na tsvyntari (At the Cemetery), Braty (Brothers), Svichka horyt (A Burning Candle) and others). Likewise Olena Pchilka authors a number of short stories (Soloviovyi spiv (Nightingale Singing), Pivtora oseledtsia (A Herring and a Half) and others); fascinating literature for children (poems Vesniani kvity (Spring Flowers), Snihova Baba (Snowwoman), Metelyk (Butterfly), Zaichatko i khlopiatko (The Little
Hare and the Boy) and others), stories (Sosonka (A Christmas Pine-tree), Kobzarevi dity (Kobzar's Children) and others), plays and different works of literary criticism.

The Ukrainian women writers were involved in the political movement aimed at unifying Eastern Ukraine (in the Russian Empire) and Western Ukraine (in the Austro-Hungarian Empire). Haywood's literary activities were also an inseparable part of the complex political landscape of eighteenth-century Britain.

Yet, these women are best remembered as the authors who, without any doubt, promoted the rise of literary journalism written by and for women in their own countries and were famous for their pioneering journalistic projects The Female Spectator and The Pershyi Vinok (The First Wreath).

The aim of this study is to give a broad outline of the women's English and Ukrainian journalistic projects, identify the features they share despite certain temporal, spatial, geographical and social differences as well as focus on the significance of the two female pioneering journals. The first stage involves a survey of basic research papers that investigate Eliza Haywood's journal The Female Spectator and The First Wreath from different perspectives. The second stage deals with giving comments on major works, themes, characters depicted in both journals. As a result of close examining Eliza Haywood's project and that of the Ukrainian authors the study illustrates that the journals in question hold great significance not only to the history of literary journalism but to protofeminist and feminist history of both countries as well.

\section{LITERATURE REVIEW}

It should be noted that in the Western academic tradition "literary journalism" is a highly debated term also known as "the New Journalism", "literary nonfiction", "creative non-fiction", "narrative nonfiction", "the literature of fact", "lyrics in prose", and, more recently, "long-form journalism", "slow journalism", and "multi-platform immersive journalism". Richard Keeble explains this terminological variety by the fact that journalism and literature have different status: "In the face of journalism's generally low cultural status, advocates of literary journalism have promoted it as a Higher Form of Journalism [9, p. 874]. However, the main goal in this article is to discuss practicing literary journalism rather than different approaches to its definition.

Early English women's literary journalism has recently become a debated issue in a number of 
academic publications shedding light on a variety of its aspects and presenting a fresh perspective on women authors as a central part of the literary scene in England. In particular, Shevelow, Osell, Beetham, Black, Barker, Berry, Prescott \& Jane Spencer, Powell have been long engaged in intellectual debates on periodicals by and for women in England. To some great extend these research papers expand our understanding of early English periodicals and magazines targeted at the woman reader.

A number of literary critics have displayed great academic interest in studying The Female Spectator authored by Haywood. For instance, Helen Koon explores social issues depicted in Haywood's journal while Felicity Nussbaum and Kathryn King give a broad outline of Eliza Haywood's being engaged in political problems in The Female Spectator. K. Girten and J. Jarvis place emphasis on Haywood's devotion to exploring natural philosophy; A. Sagal describes Haywood's subtly rebellious attempt to disrupt conventional narratives in this periodical about women's relationship to nature; E. Dowd-Arrow views The Female Spectator as a protofeminist salon providing women, both with rhetoric and space for discussing the issues of their equality and sexuality; Deborah J. Nestor, Shawn L. Maurer, Eve T. Banett, Anthony Pollock and others discuss the relationship between The Female Spectator and its 'learned brother' and predecessor - Addison and Steele's Spectator. Taking into consideration that curiosity in its visual aspect was of great importance to European culture in the eighteenth century, Juliette Merritt highlights the way Haywood exploits the narrative and the discursive possibilities of the dichotomy 'spectator / observer' in her periodical.

It should be noted that early Ukrainian women press has attracted no little scholars' attention as well. For instance, the women's early periodicals were discussed by their contemporaries - I. Franko [5], M. Grushevskyi, M. Pavlyk [17], G. Tseglynskyi, K. Malytska, M. Furtak, and others who either praised or criticized female authors' first steps in publishing. Various historical aspects of the early women press were also developed in books and academic papers by M. Lozynskyi, Y. Kravchenko, A. Chaikovskyi who researched the work of active participants involved in publishing periodicals for women. A considerable contribution was made by such researchers of the Ukrainian diaspora as M. Bohachevskyi-Chomiak [3], I. Knysh [11], M. Davydovych, L. ZalesskaOnyshkevych, L. Volynets, I. Pavlykovska. A number of modern literary critics have recently joined the discussion in question from different perspectives.

\section{ELIZA HAYWOOD AND HER JOURNAL THE FEMALE SPECTATOR}

Eliza Haywood's journalistic project The Female Spectator is generally considered to be the first periodical written by a woman writer and aimed "to address women's concerns from a woman point of view that essentially legitimizes the authority of women to do so" [23, p. 13]. It is worthwhile mentioning that journals targeted at female readership had already appeared in England since 1693, for example, John Dunton's successful periodicals the Athenian Mercury and the Ladies' Mercury. Though proclaiming female authorship and appealing to women readers as a primary audience, these journals were certainly authored, edited and produced by men.

The Female Spectator was published by Thomas Gardner in twenty four monthly books of about sixtyfour octavo pages each between April 1744 and May 1746 [22, p. 194]. After the writer's death it was translated into German, French and Italian and ranked as the third most frequently reprinted work by Haywood in the eighteenth century.

In The Female Spectator Eliza Haywood addresses her female readers whose structure is more innovative and labelled "an essay-periodical", "a miscellany", and "a courtesy book". Kathryn R. King identifies sixty literary essays in The Female Spectator [10, p.5], some of which are so well developed that Patricia Meyer Spacks likens them to miniature novels [21, p. 18].

Haywood believes that her task as a periodical essayist is to expose the follies of the age and offer a positive plan for the reformation of the era. She remarks in The Female Spectator: "the monthly essays ... are calculated for no other end than the improvement of the morals and manners of an age which stands in the utmost need of so agreeable a monitor" [7, p. 27].

Following Cicero's influential triad of rhetorical aims - "docere, movere, delectare" [4, p. 33], each book of The Female Spectator addresses a single topic in an essay that combines social commentary, advice, moral instruction and entertainment. Topics are frequently introduced by way of a conversation or a letter, and the discussion that follows is illustrated by an anecdote or a story. As Miguel-Alfonso notices, "...moral ideas expressed in abstract terms constitute the docere of the periodical, whereas the examples provide the delectare" $[15$, p. 75$]$.

The Female Spectator is traditionally referred to as a spiritual sister of "a learned brother" [7, p. 9] - the 
periodical The Spectator of Joseph Addison and Richard Steel offering a program of reforming manners and morals of readers. Likewise $M r$. Spectator's club whose members (narrators) represent different layers of civil society and ideological stances, the narrators of The Female Spectator form a society of women: "Mira, a Lady descended from a Family to which Wit seems hereditary, married to a Gentleman every way Worthy of so excellent a Wife, and with whom she lives in...perfect Harmony... Next ... a Widow of quality, who not having buried her Vivacity in the Tomb of her Lord, continues to make one in all the modish Diversions of the Times, so far... as she finds them consistent with Innocence and Honor ...The third is the Daughter of a wealthy Merchant, charming as an Angel, but endued with so many Accomplishments, that to those who know her truly, her Beauty is least distinguished Part of her" [7, p. 9]. The fourth is The Female Spectator herself.

These narrators shape the concept of the magazine - to offer advice on all matters of love and life pertaining to women. Current affairs, wars and political issues ("armies marching, - battles fought, towns destroyed, - rivers crossed and the like" [7, p. 21]) are not within "the province of the Female Spectator" [7, p. 22]. Jones defines many of Haywood's topics as those that belong to "the discourse of taste" [8, p. 103]. Haywood's aesthetic instructions include discoveries on the theatre, reading, natural philosophy, the use of tea, astronomy, and such qualities as good humour, ingratitude, and taste.

The themes in The Female Spectator also intend to rectify women affected by gambling, gaming, lying, scandal bearing, jilting, which is why in The Female Spectator the woman writer depicts only those characters "who embody virtue, or return to it after straying from the path of moral integrity" [7, p. 79] providing women with good examples to follow.

Another governing idea in the journal is the urgency of experience for middle-class women who would lead confined domestic life and were generally cut off from possibility to work and socialize. Haywood's attaches great importance to women and their concerns, principally courtship and marriage. She encourages them to find suitable and acceptable means of survival in the then society. For the first time she openly announces her doctrine of quiet rebellion: "A Modest Wife should never affect the Virago, and for her own Sake be wary, even when Most Provoked ...I have, in a Former Spectator, taken Notice, that is not by Force our Sex can hope to maintain their Influence over Men, and I again repeat it as the most infallible
Maxim, that whenever we would truly conquer, we must seem to yield" [7, p. 25].

Although the author mainly focuses on the home, she strongly argues for women's education, knowledge of the world, and a good marriage coming from the partnership of enlightened participants. Haywood claims that only an educated woman will make a fitting marriage, which will eventually ensure stability and peace in society: "The World would infallibly be more happy than it is, were Women more knowing than they generally are" [7, p. 16].

In The Female Spectator Haywood champions the education of the mind stating that "dress and show are not acceptable of a fine lady... beauty is seated in the mind" [7, p. 29]. In her opinion, education is a way for a woman to save herself as enlightenment provides her with means to establish an identity. More than a time does Haywood employ the motif of masquerade "that daring attempt to invert the order of nature" [7, p. 16], suggesting the identity - less state of most women who are bound to choose a disguise when they opt to become mentally free. In her opinion, a woman should not accept the public passive role imposed on her by society. The author assures the reader that it is education that can help the female to proper understand not only herself but also her position in society.

At first the journal seems gossipy rather than political and encourages the reader to find keys to little stories and tales, however, as early as the second number indicates emergence of the patriotic sentiment. Haywood expresses her anxiety over the moral state of the nation and society increasing "Stupidity" and "blockish Senselessness" [7, p. 258], and in the final number The Female Spectator describes herself as a more "generous and public-spirited editor" [7, p. 309]. Thus, the periodical is not only a compendium of moral instruction, virtuous reading and practical skills, but a space for grave and patriotic discussion then widely current as well.

One of the most successful and influential works authored by Eliza Haywood occupies a unique place in the history of English periodical literature. Haywood's essays provide an ideal forum for heated debate and investigation of the main problem Eliza Haywood concerned herself with throughout her life female opportunities and limitations. Being well aware of all those difficulties and restrictions imposed by a patriarchal system, she refused to accept them as such that define women's possibilities. 


\section{THE UKRAINIAN WOMEN'S JOURNALISTIC PROJECT THE PERSHYI VINOK}

One of the key points in this academic debate has invariably been a Ukrainian almanac The Pershyi Vinok, as much versatile, comprehensive and multidimensional as The Female Spectator. The journal was issued due to enormous efforts, commitment and funds supplied by two young women - Pchilka and Kobrynska who hoped to pursue publication of another almanac The Druhyi Vinok (The Second Wreath) but the plan was never realized.

Apart from Pchilka and Kobrynska The Pershyi Vinok contained texts of fifteen more women authors of different ages and social status Lesia Ukrainka (1871-1913), Liudmyla Starytska (1868-1941), Uliana Kravchenko (1860-1947), Anna Pavlyk (1855-1928), Olesia Bazhanska (1866-1906), Klymentyna Popovych (1863-1945), Sofiia Okunevska-Morachevska (1865-1926), Olha Kosach (1877-1945), Olena Hritsai (1856-1914) and others. In the almanac, these women authors addressed their powerful word to the Ukrainian female community, claimed women's narrative authority in the literary world exclusively monopolized by men and created a female space in social life.

The 454 page long anthology presents forty nine texts written by prominent and less well known women writers in a variety of genres - poems, short stories, ethnographic studies, and scientific articles. Perhaps, one of the youngest authors, a sixteen-year old Lesia Ukrainka (Olena Pchilka's daughter), contributed 3 verses and a poem Rusalka (The Water Nymph) which depicts a universally known love triangle and at the same time exposes daunting challenges and pressures faced by women peasant throughout their lives.

The same problem is also raised in a verse novel Zvychaina istoriia (An Ordinary Story) authored by Klymentyna Popovych. The woman writer tells a dramatic love story about a young beautiful woman Yaryna and her fiancé Vasyl, taking up military service. A series of events - hard work for a landowner, illegitimate pregnancy and an escape from him leads to a seemingly happy marriage to Vasyl. Yet, the man finds difficulty forgiving his wife, starts drinking and abusing her, which causes the woman's misery. Yaryna's former landowner's verdict sounds shocking: "All the poor are low-born scums" [19, p. 120].

Another author who contributes a short story $\mathrm{Na}$ chuzhyni (In Foreign Lands) to The Pershyi Vinok is
Olha Levytska. Her main character Rosa, a daughter of wealthy and respected people in Moravia, falls in love with Iwan, a demobilized soldier from Ukraine and secretly leaves her relatives to only find misery and poverty with her beloved in his native village. No matter how hard the woman tries, she is helpless to change her life circumstances - Iwan's idle and immoral life style, his unacceptable attitude to her, his selling the house to Jewish people. Rosa ends up living in the street and soon dies. Despite her honesty, kindness and diligence all she deserves at the end of her days is just a stone thrown at her coffin by a woman peasant saying: "This is for all sins of yours, my dear" [14, p. 111]. By sharing the story $N a$ chuzhyni with reading audience Olha Levytska tries to support a number of women who like Rosa were deceived by demobilized soldiers at the time and had to lead a miserable life afterwards.

A bright and talented woman Anna Pavlyk submitted to The Pershyi Vinok a short autobiographical piece of writing called Zarobinytsia (A Female Guest Worker). In this story the author depicts life of a woman guest worker who seems to experience more hardships even if compared to those of a woman peasant. Unlike the latter, who has a place to live, parents and a husband, often evil yet ready to stand up for his wife if necessary, a woman guest worker (usually an orphan) belongs to the lower layer with the only chance to marry a craftsman spending his money on drinks and abusing her physically. All she can do is to work for 12-14 hours a day, give a birth to children who are doomed to follow in her steps and end up aging rapidly.

Olena Pchilka's own contribution to The Pershyi Vinok was her story Tovaryshky (The Girlfriends). Its plot involves a group of friends from a rural part of Ukraine, both women and men, who go to Zurich and Vienna to medical school where the young people meet other Slavs, including a girl from Russia, and all become a close group of expats at college. Having gained knowledge of life and modern experience, one of the main female characters, Liuba Kalynovska, returns home to her village and begins working as a doctor and midwife. Contrary to her mother's expectations, the young woman marries her male friend, Dmytro Kornievych.

The story Tovaryshky explores not only the problem of women's emancipation and education, life and career choices, challenges accepted ideas about family, love and dependence on men. An important theme is patriotism. In the following passage the writer demonstrates her desire to introduce a female character entirely different from the ones depicted in 
Ukrainian literature before - a woman who shows her genuine loyalty to the patriotic cause: "I set out a new field though I remain - so to speak, on the fresh ground of the very same Ukrainian field, Ukrainian literature, Ukrainian life... [My heroines] are all taken from the lives of the people, though they are not the heroines of Vovchok, Kulish, or even Shevchenko (those delicate lovers, sisters, women), they are still the figures of patriot women" [Pchilka, as cited in BohachevskyiChomiak, 1999, p. 42].

Olena Pchilka creates the character of Liuba Kalynovska as the female patriotic icon. She has been brought up in an environment where she learns to love and nurture the Ukrainian language, literature, traditions. The young woman takes pride in being a Ukrainian. As a representative of a great nation, she sees her main task in sharing knowledge and experience with women compatriots.

It is not surprising that many Ukrainian women authors tended to sacrify their feminist aspirations for the sake of the national cause which was a general policy in the late nineteenth century when "Ukraine was wary of numerous attempts to 'flatten' or 'equalize' the Ukrainian language and literature exposed to Russification, Germanization, Polonization, and Romanization" [20, p. 1287]. Thus, "feminist issues such as equal rights were actually goals of the entire community; exclusively women's issues were secondary" [3, p. 460].

A sizable contribution to The Pershyi Vinok was made by Nataliia Kobrynska and included two short stories Pani Shumynska (Lady Shumynska) and Pan suddia (The Judge) as well as five academic articles presenting the author's views on women's work, education and their place in the family. A dramatic plot of Pani Shumynska centers around the fate of an aging woman married to a Polish Roman Catholic priest. She has been long accustomed to a family life governed by old traditions: sons are raised to become priests; daughters grow up and marry priests. However, her own children choose to follow a completely different way of life. Shumynska is reluctant to accept the so called "spirit of the times", which makes her feel like a victim of changing values and views. The story Pan Suddia (The Judge) depicts a moral decline of a judge who used to be an honest person advocating people's rights but the existing hypocrisy and immorality of the then world turn him into an individual whose only concern is money. In his review Pershi stupni rusko-ukrainskoho zhinotstva (The First Steps of Russian and Ukrainian Women) Mykhailo Pavlyk gives the writer credit for a welldeveloped plot and characters in Pani Shumynska, though, in his opinion, "Kobrynska's strength is not so much in short stories but in academic articles on women, which enhance understanding of women's issue and make this book valuable" [17]. Nataliia Kobrynska introduces theoretical and empirically grounded arguments on women's movement in such articles as Ruske zhinotstvo $v$ Halychyni $v$ nashykh chasakh (Russian Women in Halychyna in Our Time), Perednye slovo do almanachu (An Introduction to the Almanac), Pro rukh zhinochyi $v$ novishykh chasakh (Women's Movement in New Time) and Pro pervisnu tsil Tovarystva ruskykh zhinok $v$ Stanislavovi (The Essential Aim of Association of Russian Women in Stanislav).

In one of her best articles Ruske zhinotstvo $v$ Halychyni $v$ nashykh chasakh [12] Kobrynska describes poor working conditions of local peasant women and emphasizes an inferior status of women and a negative attitude to them. The writer seeks to express her gender concern and portrays an atmosphere in which the woman establishes her identity and constructs a new set of value orientations based on self-awareness, readiness to revolt against routine and willingness to discover a civic-minded individual in herself.

Anna Pavlyk's sister, Kateryna Dovbenchuk, presents in The Pershyi Vinok an ethnographic study Divka i kniagynia, narodni obychai z Kosivshchyny (The Maiden and the Princess, Folk Customs of Kosiv Area). Here the woman writer describes an extremely hard life of female peasantry inhabiting one of the most picturesque spots in Ukraine - the Hutsul region. Her focal point is existing social and cultural norms of local people, in particular, young men / women relationships when they first start dating as well as a man's changing attitude to a woman once she becomes a spouse with no other subsequent alternative but to be a household maid and obey her husband. Pavlyk emphasizes that from all the literary pieces written by Galyciian women authors for The Pershyi Vinok, "Kateryna's language is the most beautiful and so much close to real language spoken by common people, which is not surprising at all as Dovbenchuchka herself is a peasant and even illiterate: her bother wrote down all her stories" [17].

The significance of the journal The Pershyi Vinok in the history of Ukrainian journalism and literature is tremendous. In Solomiia Pavlychko's words: Olena Pchilka and Nataliia Kobrynska laid the foundations of a different tradition, in which there were no male pseudonyms, no male narrators, basically no attempts to imitate a male voice. Owing to these authors in 
Ukrainian literature there appeared an intellectual female voice as well as a feminist idea [16, p. 69-70].

According to Halyna Koscharsky the edition The Pershyi Vinok took an unprecedented step of featuring only women writers and saw its goal in the raising of the social and political consciousness of Ukrainian women [13, p. 309]. Iwan Franko regarded publishing women's literary works in The Pershyi Vinok as "the first proof that a national feeling was awakening at the very heart of Ukrainian people and involving those social layers that traditionally had difficulty realizing it” [5, p. 503].

Evaluating contribution of the first anthology written by and for women to world literature Irene Knysh claims that "The Pershyi Vinok has a special and significant place considering its wide range of themes, an unusual way of their interpretation and a deep ideological approach reflecting feelings and ideals of young Ukrainian women inspired by new challenges" [11, p. 96].

\section{CONCLUSION}

The results of this research paper clearly indicate that despite so many apparent differences related to geography, historic epochs, languages and social status of the women authors, the journals The Female Spectator and The Pershyi Vinok share a number of common features. In the first place, both the projects are a true milestone in the evolution of English and Ukrainian literary journalism.

It is more than to the point to emphasise that these periodicals opened up a new era of conquering the domain originally taken by men. Haywood, Kobrynska, Pchilka and others turned out to be able story-tellers who accurately describe the times of their own though none of the women were a chronicler of the history in general.

These authors were efficient women journalists with great narrative powers who could show life from a woman's perspective providing the reader with broad and deep understanding of what it is like to be a woman in English eighteenth-and Ukrainian nineteenth century society respectively.

The fictional and non-fictional experiments presented in the journals share the most comprehensive treatment of womanhood in the period. Haywood, Kobrynska, Pchilka and others create heroines en masse whose experience allows the reader to see the patters of feminine behaviour from the recurring themes, motifs, myths. Their heroines give direct and indirect details to exterior and interior life in the then England and Ukraine by exploring the problem of quest for feminine identity within the social context.

These fascinating journalistic projects hold a significant place in proto-feminist and feminist history of both countries considering the fact that they made women's concerns sound palatable and important as well as assisted English and Ukrainian women to define their normative roles in the then societies.

\section{AUTHORS' CONTRIBUTIONS}

All the authors made an equal intellectual contribution to the submitted article. In particular, L. Lutsenko developed the conception of the research, presented Haywood's literary criticism on The Female Spectator. I. Dyrda participated in drafting the article, translating quotations from Ukrainian into English and formatting references. A. Tomilina participated in drafting the article and preparing the survey of several poetic works contributed by the Ukrainian women authors to the journal The Pershyi Vinok. M. Maloivan participated in drafting the article as well collecting and analysing research papers available on women's 19th century press in Ukraine. I. Zorenko helped to coordinate the authors' work, participated in drafting the article and analysing some of the short stories from The Pershyi Vinok. All authors made a critical revision of the article and approved of the final version of the manuscript to be published.

\section{REFERENCES}

[1] D. Baker, I. Reed, Biographia Dramatica, or, a Companion to the Playhouse, vol. 1, AMS, New York, 1966, p. 316.

[2] M. Bohachevskyi-Chomiak, Bilym po bilomu: Zhinky v hromadskomu zhytti Ukrainy [White on White: Women in Ukrainian Public Life], Lybid, Kyiv, 1999.

[3] M. Bohachevskyi-Chomiak, Feminists Despite Themselves: Women in Ukrainian Community Life, 1884-1939, Canadian Institute of Ukrainian studies, Edmonton, 1988.

[4] D. Clark, Rhetoric and Poetry in the Renaissance, Columbia University Press, New York, 1922.

[5] I. Franko, Zibrannia tvoriv u 50 tomakh [Collected Works in 50 Volumes], vol. 41, Naukova Dumka, Kyiv, 1984.

[6] E. Haywood, Fatal Secret, Or, Constancy in Distress. In Celebration of Women Writers, 1725. 
http://digital.library.upenn.edu/women/haywood /fatal/fatal.html.

[7] E. Haywood, Selections from the Female Spectator by Eliza Haywood, in: P. Spacks (Ed.), Oxford University Press, New York, Oxford, 1999.

[8] R.W. Jones, Eliza Haywood and the Discourse of Taste, in: Authorship, Commerce and the Public, Palgrave Macmillan, London, 2002. DOI: http://doi.org/10.1057/9780230375482_7.

[9] R.L. Keeble, Literary Journalism as a Discipline: Tom Wolfe and Beyond, Brazilian Journalism Research 14 (3) (2018) 862-881. DOI: http://doi.org/10.25200/BJR.v14n3.2018.1126.

[10] K. King, A. Pettit, Introduction to The Female Spectator, by Eliza Haywood, in: K. King, A. Pettit (Eds.), The Selected Works of Eliza Haywood, vol. 2, Pickering \& Chatto, London, 2001, pp. 1-11.

[11] I. Knysh, Smoloskyp u temriavi. N. Kobrynska i ukrainskyi zhinochyi rukh [The Torch in the Darkness. N. Kobrynska and Ukrainian Women's Movement], Novyi Shliakh, Vinnipeg, 1957. http://diasporiana.org.ua/wpcontent/uploads/books/16744/file.pdf.

[12] N. Kobrynska, Ruske zhinotstvo v Halychyni v nashykh chasakh [Russian Women in Halychyna in Our Time], in: Pershyi Vinok: Zhinochyi almanakh [The First Wreath. Women's Almanac], Lviv, 1887, pp. 3-17.

[13] H. Koscharskyi, Ukrainian Feminist Poetry: Is it Coming of Age?, Canadian Slavonic Papers, Revue Canadienne des Slavistes 45 (2003) 307316.

[14] O. Levytska, Na chuzhyni [In Foreign Lands], in: Pershyi Vinok: Zhinochyi almanakh [The First Wreath. Women's Almanac], Lviv, 1887, pp. 106-112.

[15] R. Miguel-Alfonso, Social Conservatism, Aesthetic Education, and the Essay Genre, in: L. Wright, D. Newman (Eds.), Fair Philosopher, Eliza Haywood and the Female Spectator, Bucknell University Press, Lewisburg, 2006, pp. 72-81.

[16] S. Pavlychko, Dyskurs modernizmu v ukrainskii literaturi [Discourse of Modernism in Ukrainian literature], Lybid, Kyiv, 1999.
[17] M. Pavlyk, Pershi stupni rusko-ukrainskoho zhinotstva [The First Steps of Russian and Ukrainian Women], Narod 4 (1890) 42-50 https://zbruc.eu/node/47728.

[18] O. Pchilka, Tovaryshky [The Girlfriends], in: Pershyi Vinok: Zhinochyi almanakh [The First Wreath. Women's Almanac], Lviv, 1887, pp. 231-359.

[19] K. Popovych, Zvychaina istoriia [An Ordinary Story], in: Pershyi Vinok: Zhinochyi almanakh [The First Wreath. Women's Almanac], Lviv, 1887, pp. 112-120.

[20] C. Kramarae, D. Spender (Eds.), Routledge International Encyclopedia of Women: Global Women's Issues and Knowledge, vol. 3, Routledge, New York \& London, 2000, p. 1287.

[21] P. Spacks, Introduction, in: Selections from the Female Spectator by Eliza Haywood, Oxford University Press, New York, Oxford, 1999.

[22] P. Spedding, Measuring the Success of Haywood's Female Spectator, in; L. Wright, D. Newman (Eds.), Fair Philosopher: Eliza Haywood and the Female Spectator, Bucknell University Press, Lewisburg, 2006, pp. 193-211.

[23] L. M. Wright, D. J. Newman, Introduction, in: L. M. Wright, D. J. Newman (Eds.), Fair Philosopher, Eliza Haywood and The Female Spectator, Bucknell University Press, Lewisburg, 2006, pp. 13-17. 